\title{
CZY POWSTANIE W ROKU 1863 BYŁO NIEUCHRONNE? \\ Zapis dyskusji redakcyjnej odbytej 11 marca 2013 r. z udziałem Jerzego W. Borejszy, Andrzeja Nowaka, Jerzego Zdrady, prowadzonej przez Macieja Janowskiego
}

Maciej Janowski: Proponowałbym, abyśmy spróbowali odpowiedzieć na następujące pytania: Jak wybuchają powstania i dlaczego właściwie wybuchło powstanie styczniowe, jakie procesy i jakie indywidualne decyzje do niego doprowadziły? Z powyższym wiąże się pytanie o subiektywną ocenę sytuacji przez aktorów wydarzeń: jakie były horyzonty oczekiwań i granice kompromisów? Czego spodziewali się dążący do powstania czerwoni, czego biali (i to różni biali: inna rzecz Karol Ruprecht czy Edward Jurgens, inna rzecz hrabia Andrzej Zamoyski i jego zwolennicy), czego zaś margrabia Aleksander Wielopolski? Jak oceniali sytuację wewnętrzną i międzynarodową? A jakie były oczekiwania władz rosyjskich? Na ile gotowe były one ustąpić, aby w ten sposób kupić sobie spokój w Królestwie? Jak wyobrażano sobie rozwiązanie kwestii narodowościowej w przyszłej odbudowanej Rzeczypospolitej? Czy były jakieś konkretne projekty ustrojowe ewentualnego trializmu (sugerowanego przez potrójny herb powstańczy)? Czy można powiedzieć, że powstanie styczniowe jest ruchem szlacheckim? Czy uzasadnione jest twierdzenie o specyficznych cechach szlacheckiego ruchu politycznego? A może tezy o szlacheckości powstania nie da się utrzymać ze względu na rolę w nim inteligencji, a może i mieszczaństwa? Jakie możliwości działania i wymuszania posłuchu miało państwo podziemne. Autorytet pieczątki w sytuacji ciągłej rywalizacji wewnątrz władz powstańczych.Jak w świetle prasy powstańczej wyglądały cele ruchu, obraz wroga, wyobrażenia o świecie? Jak wyglądały indywidualne dylematy: jednostka wobec powstania, wobec dwuwładzy powstańczej i zaborczej; postawy wobec śledztwa. Nie wiem natomiast, czy powinno być głównym tematem rozmowy to, 
czy powstanie było dobre czy złe. Zadanie pytania o szanse powstania jest $\mathrm{w}$ istocie zadaniem pytania o to, czy bić się czy nie.

Jerzy Borejsza: Absolutnie to nie jest to samo.Jerzy Jedlicki w książce Droga do narodowej klęski $i^{1}$ mówi od razu na początku: powstanie nie miało żadnych szans i koniec. Powstanie z dzisiejszego puntu widzenia nie miało żadnych szans, ale powstanie z tamtego punktu widzenia to są dwie różne rzeczy. Problemy powstania, tak jego przyczyn, jak i szans czy następstw, można rozpatrywać tylko w określonym wymiarze czasowym. Przyczyny powstania widziane oczyma świadków z lat 1861-1863 były różnorodne. Dla historyka Henryka Lisickiego to kolejna próba „narodowego samobójstwa”. Ale z kolei, jak to lapidarnie ujął w czasie piątej rocznicy powstania na obchodach w Brukseli pułkownik Zygmunt Miłkowski (znany jako pisarz Teodor Tomasz Jeż), powstanie „było nieuchronnym. Jak woda ze źródła wypłynęło z samej natury niewoli". Część elit narodu polskiego, wyraźna i najbardziej czynna, nie godziła się od dziesięcioleci na utratę własnego państwa. Kiedy sprzyjała koniunktura międzynarodowa, Polacy chwytali za broń (czasy Napoleona I, Wiosna Ludów 1848/1849). Podczas wojny krymskiej (18531856) Polacy się nie ruszyli.Zbyt bliska była rzeź galicyjska (1846), która odstraszyła od wszelkich ruchów politycznych szlachtę; zbyt bliskie były klęski Wiosny Ludów (powstania w Poznańskiem i powstania węgierskiego z Józefem Bemem i innymi Polakami wśród przywódców). I jeszcze jeden bardzo ważny czynnik, którego historycy często nie zauważają: podczas wojny krymskiej Napoleon III nie zachęcał Polaków do powstania, co więcej, Francuzi i Anglicy nie dopuścili do tego, aby sprawa polska wypłynęła na kongresie pokojowym w Paryżu w roku 1856. Potem nadeszła wojna 1859 r., w której Napoleon III rzucił swe wojska na pomoc Włochom, walczącym z zaborcą Polski - Austrią. Krwawa wojna zakończyła się zwycięstwem i wymusiła liberalizację imperium Habsburgów. W marcu 1861 r. ogólnowłoski parlament proklamował Królestwo Włoch. Powstała tam na krótko wprawdzie, bo interweniował skutecznie rząd rosyjski, żądając zamknięcia instytucji - szkoła wojskowa, przygotowująca polskich oficerów do powstania (1861). Wykładał w niej Marian Langiewicz, przyszły dyktator, uczyło się trzystu elewów. Wydarzenia na Półwyspie Apenińskim miały wpływ na ziemie polskie i odbijały się nawet pewnym echem dalej w Rosji.Czytałem dwa lata temu dokumenty policji z guberni kazańskiej, w których raportuje się o nastrojach, jakie wzbudzały wieści o Giuseppe Garibaldim.

Polityka Napoleona III w sprawach narodowości, ingerencje francuskie na rzecz tworzącej się Rumunii (1859-1861) wydawały się zapo-

${ }^{1}$ J. Jedlicki, Droga do narodowej klęski, Warszawa 2013. 
wiadać, że tym razem Francja nie pozostawi swoich głównych tradycyjnych zwolenników w Europie Wschodniej - Polaków. I potem, kiedy powstanie już wybuchło, przychodzą słowa zachęty Napoleona III: „Durez!” (trwajcie). Brzmiało to dla księcia Władysława Czartoryskiego jak zapowiedź nie tylko not dyplomatycznych, ale i dalszych kroków możliwej interwencji.

Postawa Napoleona III zadecydowała o tym, że Czartoryski, początkowo przeciwny powstaniu, wiosną został głównym agentem dyplomatycznym Rządu Narodowego. Jego przykład podziałał na wielu białych, liczących na interwencję, a nawet zbrojne ruszenie się mocarstw zachodnich. Od złudzeń tych nie był wolny jeszcze i Romuald Traugutt, narzucając się jako dyktator powstania 17 października $1863 \mathrm{r}$.

Sytuacja międzynarodowa a także wewnętrzna Rosji zdawała się sprzyjać planom wybicia się na autonomię bądź nawet niepodległość. Ale okazało się, że szanse te są pozorne. Napoleon III od 1861 r. był uwikłany w ekspedycję militarną w Meksyku. Londyn skłonny był domagać się od Petersburga powrotu do ustaleń kongresu wiedeńskiego z 1815 r., ale nie zamierzał interweniować zbrojnie w Polsce.

Maciej Janowski: Kontynuujmy ten wątek. Jak zatem wybuchają powstania? Co takiego działo się w Królestwie Polskim, że do wybuchu powstania doszło? Na ile był to mechanizm immanentny, zawarty w samej sytuacji kraju?

Sytuacja rewolucyjna, czyli jak wybuchają powstania

Jerzy Borejsza: Zadziałał tu ponaddziewiętnastowieczny mechanizm, powtarzający się czy to w Afryce, czy to w Azji. Jako student czwartego roku Uniwersytetu Moskiewskiego miałem za zadanie napisanie pracy o uwłaszczeniu „Normy prawne reformy włościańskiej 1861 r.”. Wówczas nie używało się pojęcia powstanie, lecz rewolucja lub sytuacja rewolucyjna. Właśnie w latach 1859-1861 w Rosji mieliśmy, zdaniem historyków rosyjskich, do czynienia z sytuacją rewolucyjną na wsi. W 1862 r. zaczęła ona zanikać. Reformę wdrażano, chłop rosyjski zrozumiał, że będzie lepiej.W Polsce była grupa wśród czerwonych - jak bardzo liczna, to jest inny problem - która liczyła na sojusznika rosyjskiego i nawet zawarła z nim formalne porozumienie, bez większego znaczenia wprawdzie. Mówimy o „Ziemli i Woli”.

Kiedy wybuchają powstania, bunty, rewolucje? Niewątpliwie za przyczyną napięć społecznych, ale i dlatego, że liberalizacja systemu bywa brzemienna rewolucją. Gdy w systemie autorytarnym lub w totalitarnym następuje złagodzenie, to masy domagają się większych ustępstw. Z taką sytuacją wewnętrzną mieliśmy do czynienia w Królestwie Polskim. 
Maciej Janowski: Czy klęska Rosji w wojnie krymskiej nie przyczyniła się trochę do osłabienia poczucia - które w powstaniu listopadowym dominowało wśród wyższych rang wojskowych, pamiętających rok 1812 - że Rosja, która największego bohatera naszych czasów pokonała, jest w zasadzie niepokonalna.

Jerzy Borejsza: Tak, oczywiście. Pogromcy Napoleona, dusiciele Wiosny Ludów, okazali się przeciwnikiem do pokonania. Zaczęto targać niedźwiedzia za uszy. Polecam tu ilustracje z wydanej w 2013 r. w Warszawie książki Europa i niedźwiedź ${ }^{2}$ o obrazie Rosji w karykaturze światowej. W dobie wojny krymskiej kpiny z carskiej Rosji osiągają apogeum. Niewątpliwie, to dociera do Polaków, tych, którzy czytają, nie upowszechniając tego na cały jeszcze nieistniejący naród. To jest bardzo świadoma propaganda pokazująca, że pomściliśmy - tj.ja Napoleon III - Napoleona I. Francja wymazała hańbę Berezyny i wszystko, co się z tym wiązało.

Maciej Janowski: Prof. Borejsza wymienił trzy okoliczności, wzmacniające szanse wybuchu powstania. Pierwsza to sytuacja rewolucyjna w Rosji związana z problemem agrarnym. Druga to sytuacja wewnętrzna w Królestwie, kiedy liberalizacja nabrzmiewa rewolucją, trzecia - sytuacja międzynarodowa, związana ze zjednoczeniem Włoch, Rumunii, z podkreślaniem przez Napoleona III roli protektora narodowości.

Jerzy Zdrada: Może zacznijmy od tej sytuacji rewolucyjnej w Rosji. To jest jeden z mitów historiografii: powstanie styczniowe wybuchło dlatego, że w Rosji była sytuacja rewolucyjna.

Jerzy Borejsza: Ja tego nie powiedziałem.

Jerzy Zdrada: Od tego zacząłeś. Taki jest wydźwięk. Sytuacja rewolucyjna w Rosji została wyolbrzymiona przez historiografię rosyjską, a przedtem była wyolbrzymiona przez ideologię rosyjskich ruchów rewolucyjnych, i to celowo, gdyż trzeba było pokazać jakąś genealogię, że coś tam się zaczęło. Jerzy Borejsza: Przepraszam, a bunty chłopskie?

Jerzy Zdrada: Bunty chłopskie były stale. W XIX w. takich buntów naliczono blisko 700. Historiografia radziecka zrobiła ogromny katalog tych wszystkich buntów. Bunty chłopskie, tak samo jak bunty chłopów u nas, w Królestwie, były immanentną cechą sytuacji ekonomicznej na wsi. W Rosji nazywa się to ruchem rewolucyjnym, w Polsce nazywa się to zamieszkami w takim czy innym w powiecie, niepokojami. Natomiast wpływ tych buntów na powstanie sytuacji rewolucyjnej to są zupełnie inne rzeczy i tego ja bym nie mylił. Oczywiście Polacy wiedzieli, że tam jest napięcie. Przecież Polacy tam mieszkali. Te same stosunki i ta sama

\footnotetext{
${ }^{2}$ A. de Lazari, O. Riabow, M. Żakowska, Europa i niedźwiedź, Warszawa 2013.
} 
reforma obejmowała gubernie zachodnie. Wiedziano dobrze, jaki jest nastrój na wsiach. Natomiast żeby się na tym opierać...

Jerzy Borejsza: Mówiłem, że na to liczono. Tylko tyle. Liczono też przed powstaniem na poparcie chłopów polskich dla insurekcji. I, jak wykazał między innymi historyk Wacław Nowak, poważnie się przeliczono.

Jerzy Zdrada: Właśnie. Czy naprawdę liczono na bunty chłopskie w Rosji? Na co liczył Jarosław Dąbrowski? Na spisek w wojsku. W carstwie? Nie, na spisek w wojsku carskim w Królestwie! Otóż żołnierz rosyjski czy oficer rosyjski nie bardzo chciał strzelać do bezbronnego Polaka na ulicach. I to jest faktem. To było coś, na czym budowano możliwość uzyskania pomocy w chwili wybuchu w Polsce.

Jerzy Borejsza: A kółko oficerów?

Jerzy Zdrada: Owszem, mówi się o kółku oficerów. Bardzo bym chciał zobaczyć jakieś teksty Zygmunta Sierakowskiego mówiące o tym, że liczy na rewolucję chłopską w Rosji. To kółko Polaków, m.in. rosyjscy przyjaciele Dąbrowskiego, wydawało „Wielkorusa”, ale to był polski pomysł.

Jerzy Borejsza: Przypomnijmy więc, na czym polegał ten pomysł.W 1857 r. zawiązało się w Petersburgu pod kierownictwem Sierakowskiego Koło Oficerów Polskich. W 1861 r. na terenie Królestwa Polskiego i na ziemiach zabranych powstała swoista ekspozytura tego koła: Komitet Oficerów 1 Armii, którym kierował Dąbrowski. Stefan Kieniewicz pisze, że kółka skupione wokół Sierakowskiego i Dąbrowskiego gromadziły około 170 osób - „w jednej trzeciej Rosjan, Ukraińców i członków innych narodowości”. Kółka te propagowały współpracę polskich i rosyjskich oficerów. Polegała ona nie tylko na czynnym udziale Rosjan i Ukraińców w powstaniu. Ponadto udzielano pomocy w ucieczkach z więzień i opóźniano akcje bojowe niektórych oddziałów w Królestwie.

Jerzy Zdrada: Zgoda, wszystko w porządku. Część wojskowych się angażowała, część nie - podobnie było w przypadku Polaków. Przecież nie wszyscy Polacy z tego kółka oficerów Sierakowskiego i Dąbrowskiego poszli do powstania. Opowiedzenie się w momencie wybuchu powstania po jednej czy drugiej stronie to był wybór - wybór indywidualny, motywowany najrozmaitszymi czynnikami, również i rachunkiem szans - opłaca się, nie opłaca? Co stracę? To byli zawodowi wojskowi. Mieli rodziny. Co innego deklaracja przed akcją, a co innego pójście na akcję, jeśli już użyjemy tego języka warszawsko-powstańczego. Co innego nastrój kompanii, która nie chce strzelać do bezbronnych ludzi, a co innego sytuacja, kiedy ona musi stanąć do walki o północy, kiedy powstańcy atakują koszary. W tym momencie następuje radykalny podział i niweczy się najrozmaitsze plany. nie możemy zapominać też o celowych działaniach rosyjskich władz wojskowych, które dobrze wiedziały, co się szykuje, 
i wyprowadzały, zmieniały całe garnizony, chociażby ten przysłowiowy Modlin, na który liczono. Takich planów nie da się do końca ukryć. Można ukryć zamach na Franza Kutscherę, ale nie można ukryć decyzji o powstaniu.

Maciej Janowski: Pewnie można ukryć jego datę.

Jerzy Zdrada: Część oficerów rosyjskich doskonale o tym wiedziała, bo była przez polskich konspiratorów poinformowana, gdyż myślano, że pomogą. Zarówno na wschodniej granicy Królestwa, jak i pod Kaliszem. Wtajemniczeni oficerowie rosyjscy szli pojedynczo, ale już się nie decydowali na wyprowadzenie swych żołnierzy. Wysłannicy Komitetu Centralnego, którzy pojechali do Aleksandra Hercena, a potem, kiedy Padlewski pojechał do Petersburga negocjować z Futinem i innymi na temat związków, nie liczyli na wybuch powstania. Liczyli na sojusz ideowy, poparcie moralne. Otrzymali takie poparcie od Hercena. Czy ono się okazało realne? W mojej ocenie nie. Maciej Janowski: Ono się okazało brzemienne w skutkach ideowych. Gdyby tego nie było, to byłoby pewnie gorzej, w każdym razie na dłuższą metę.

Jerzy Zdrada: Nie dla Hercena. Hercen zdecydował się, wiedząc - tak jak znam tę literaturę i się wczuwam w tę sytuację - że sprawa jest przegrana. Decydował się z pełną świadomością, że on też może na tym przegrać. Andrzej Nowak: Na krótką metę jest przegrana, doraźnie.

Jerzy Zdrada: Hercen prawdopodobnie nie spodziewał się, jak bardzo może przegrać. Nie czuł tego jeszcze, co już czuli niektórzy Polacy, uciekając z Moskwy. Taki Henryk Wieliński, mało znany, który uciekł spod opieki Katkowa, bo on przed powstaniem w 1861 r. dobrze wiedział, jak zmieniają się nastroje wśród liberałów rosyjskich posewastopolskich typu Katkowa i całego tego grona. I on mówił o tym do Hotelu Lambert - że nie ma szans na to, żeby to środowisko w jakiś sposób dalej sprzyjało. To nie wybuch powstania dopiero skłonił Katkowa do jednoznacznego opowiedzenia się przeciw polskim aspiracjom. Wybuch powstania przyspieszył i ułatwił tę ewolucję postaw. Dobrze wiedziano, że nie idzie o Królestwo, tylko o Polskę w granicach z 1772 r., czyli sprawa dotyka najżywotniejszych interesów rosyjskich, a nie tylko ewentualnych pozycji Rosji. Wobec tego w przypadku „Ziemli i Woli” powtarzam, chodziło o moralne poparcie.

Jerzy Borejsza: Plany Dąbrowskiego były przecież oparte na istniejących oficerach, których wykorzystał.

Jerzy Zdrada: Dąbrowski już sobie w 1862 r. dobrze zdawał sprawę, że nie jest to takie oczywiste. Całe parcie Dąbrowskiego, żeby zrobić powstanie w końcu czerwca lub lipcu 1862 r., wynikało stąd, że już widział zmianę nastrojów. Zdawał sobie sprawę, że potem będzie gorzej. Jako oficer w sztabie dywizji wiedział, że po wykryciu tego - nazwijmy to: spisku - Franciszka 
Rostkowskiego, Piotra Śliwickiego i ich rozstrzelaniu atmosfera się pogorszy. Wszystko to się sprawdziło. Wyprowadzono ten garnizon, na który on liczył. Aliści wiedzieli to również ci, którzy nie chcieli wtedy powstania. To są szczegóły, ale jeśli mówimy o tym , co nas czekało ze strony Rosji, oraz ewentualnej pomocy, to mówmy o wszystkich rzeczach, a nie o pewnych tylko. Faktu, że była współpraca, można było potem użyć jako wiana do współpracy w następnej epoce. I używano tego ze skutkiem pozytywnym, bo było się do czego odnieść.

Patrzę na powstanie styczniowe nie tylko w tej krótkiej perspektywie od wojny krymskiej aż do wojny austriacko-francuskiej. Powstanie styczniowe trzeba rozpatrywać w całym ciągu ruchów wyzwoleńczych czy narodowo-wyzwoleńczych, jak się kiedyś mówiło, czy niepodległościowych ówczesnej Europy. Powstanie polskie to nie jest przecież wyjątek. Ono w tym obszarze Europy, w którym się znajdowaliśmy, czyli Europy Środkowej, odliczając Bałkany, było ostatnim powstaniem tego typu. Na Bałkanach powstania trwały dalej, bo tam była zupełnie inna sytuacja. Jeżeli tak na to powstanie spojrzymy, to zrozumiemy, dlaczego było ono ostatnim polskim powstaniem.

Jerzy Borejsza: Sojusznicy Polaków dostali wszystko przedtem (lub niebawem po 1864 r.).

Jerzy Zdrada: Tak, a jeden potencjalny, który od wojny Wiosny Ludów już nie był potencjalny, czyli Niemcy, dostał nieco później, ale też wszystko. Oni już wiedzieli, że dostaną. Natomiast u wszystkich innych zostały zakończone procesy zjednoczeniowe, narodowe, dobijania się do systemu rządów reprezentacyjnych itd. Jeśli spojrzymy na to powstanie jako na rzecz, która się wpisuje w cały europejski ruch - nazwijmy to - rewolucyjny, to mamy tu odpowiedź na Pana pierwsze pytanie, dlaczego musiało wybuchnąć powstanie i czy musiało. Musiało w tym sensie, że byliśmy zbyt dużym narodem bez niepodległości, za dużą historię mieliśmy i doskonale rozumieliśmy, że nie walczy się o jakąś niepodległość, która jest takim hasłem, takim pustym hasłem retorycznym. Walczy się o niepodległe państwo, które zapewni społeczeństwu rozwój lepszy, niż mogły to zapewnić wszystkie działania organicznikowskie w ramach tych struktur, które istniały. Działania organicznikowskie w państwach praworządnych (w tym sensie, że miały konstytucję, jak w zaborze pruskim) mogły przynosić pewne efekty; można się było na czymś oprzeć, jak w Galicji. Natomiast w zaborze rosyjskim rozumianym szeroko - jako Królestwo jak i ziemie zabrane - takich możliwości i gwarancji nie było. To jest powód zasadniczy. Jedno z dalszych Pana pytań dotyczy tego, kto robił powstanie - czy ono jest szlacheckie, czy inteligenckie? Właśnie dlatego, że ono było inteligenckie, to walczono o państwo, bo dla inteligencji państwo jest 
najważniejsze. To pokolenie dobrze wiedziało, że te warunki, które są, nie dają możliwości pełnego rozwoju. My bardzo chętnie piszemy rozprawy, jak to świetnie mimo zaborów nauka się rozwijała - pamiętamy o dokonaniach Marii Skłodowskiej-Curie, o tym, że skropliliśmy tlen (Karol Olszewski i Zygmunt Wróblewski w Krakowie w 1883 r.). To wszystko prawda. Prawdą jest też, że brak polskiego państwa powodował takie straszne rozejście się sytuacji na ziemiach polskich, że ani autonomia galicyjska nie była w stanie tego zniwelować, bo największa grupa narodowa była takich możliwości pozbawiona. Dlatego powstanie musiało wybuchnąć. Maciej Janowski: Podsumujmy. Prof. Borejsza przedstawił w trzech punktach przyczyny wybuchu powstania, a odpowiedź prof. Zdrady była polemiką z punktem dotyczącym sytuacji rewolucyjnej w Rosji. Doszedł natomiast w wypowiedzi prof. Zdrady czwarty punkt - widzenie powstania styczniowego w szerszej perspektywie ruchów narodowych, zjednoczeniowych, niepodległościowych polskich, ale i innych narodów w Europie Środkowo-Wschodniej. W tej makrohistorycznej perspektywie powstanie, jeśli dobrze rozumiem myśl Pana profesora, było pewną nieuchronnością, a przyczyniał się do tego fakt, że w państwie niepraworządnym, jakim była Rosja, osiągnięcia organicznikowskie nie miały gwarancji trwałości. Do tego chciałbym potem wrócić.

Jerzy Borejsza: Prof. Zdrada hokejowo wszedł w temat, a ja specjalnie zastrzegłem się od początku, że nie mówię o sytuacji rewolucyjnej w Rosji (specjalnie używając tego pojęcia, jakie było używane) dlatego, że ona była najważniejsza, ale dlatego, że to pomijanie sytuacji wsi rosyjskiej po uwłaszczeniu, wpływu tej sytuacji na myślicieli rosyjskich, na oficerów itd., było bardzo widoczne. Czerwoni spodziewali się czegoś więcej. Dąbrowski był z natury swojej ryzykantem, ale i stąpał twardo po ziemi. To było w jego kalkulacjach nie tylko przedpowstańczych: choć ryzykował, liczył jednak realnie na oficerów rosyjskich, na kolegów.

\section{Powstania - kontekst porównawczy i imperialny}

Andrzej Nowak: Bardzo dobra wydaje mi się propozycja spojrzenia porównawczego na powstania - nie tylko w ciągu powstań polskich od XVIII w. po XX, ale także innych antyimperialnych powstań w Europie i na świecie w XIX i XX w. To jest bardziej ciekawy i niezrealizowany wciąż postulat badawczy. Trochę materiału do refleksji dostarczają książki, takie jak np. Adama Zamoyskiego Holy madness czy Jamesa Billingtona Fire in the minds of $m^{3} n^{3}$, gdzie pokazany został fenomen „globalnej” ideologii powstańczej, je-

\footnotetext{
${ }^{3}$ A. Zamoyski, Holy Madness. Romantics, Patriots, and Revolutionaries, 1776-1871, Lon-
} 
śli można tak dla uproszczenia powiedzieć, rodzącej się w XVIII w. i miejsca, jakie Polska, polscy praktycy i teoretycy zajmowali w rozprzestrzenianiu tej ideologii na całą nie tylko półkulę wschodnią, ale i zachodnią (do Ameryki Łacińskiej dotarły przecież tłumaczenia podręczników partyzantki Henryka Kamieńskiego). Generalnie powstania, wystąpienia przeciwko władzy można podzielić na dwie grupy: występuje się przeciwko władzy w kraju suwerennym lub występuje się przeciwko władzy w kraju, który jest zarządzany z zewnątrz. Czymś innym będzie rewolucja we Francji czy w Rosji, a czymś innym będzie właśnie powstanie w Polsce czy Afryce bądź Azji przeciwko władzy kolonialnej. To jest pierwsza istotna różnica. W każdym powstaniu kluczowe znaczenie ma podział w elitach - bez niego nie da się doprowadzić do powstania i jednocześnie wystąpienie mas. Oraz gotowość mas do wyjścia na ulicę (czy do lasu), jakieś powody, które pozwalają wykorzystać je w planie powstania, pewnego ruchu i łączą się z podziałem występującym w elitach. W przypadku państw zależnych czy peryferii zależnych podbitych krajów dobrej systematyki tego zjawiska dostarcza norweski radykalny badacz Johan Galtung, który mówił o tym, że do dobrego funkcjonowania takiej władzy uzależniającej peryferie od centrum potrzebna jest kolaboracja elit peryferii z elitą centrum. Do skutecznego powstania - to już mój dodatek do koncepcji Galtunga - potrzebne jest współdziałanie kontrelity peryferii (nasi „czerwoni”) z kontrelitą imperialnego centrum (rewolucjoniści w Rosji) lub bodaj nadzieja na wykorzystanie pojawienia się takiej kontrelity w centrum, która je zasadniczo osłabi. $\mathrm{W}$ istocie ta sprawa wydaje mi się kluczowa w odpowiedzi na pytanie postawione przez prof. Janowskiego o przyczyny wybuchu powstania. Dlaczego? Jeśli mówić o jakiejś „sytuacji rewolucyjnej” w Polsce - to zresztą pojęcie wprowadzone przez szkołę Milicy Nieczkiny dla zagadnień rosyjskich ściśle, ale można spróbować je tutaj dla naszych potrzeb roboczych uogólnić - to myślę, że taka „sytuacja rewolucyjna”, najważniejsza dla Polski, pojawiła się już w XVIII w., odkąd pojawiło się słowo „niepodległość” (do wokabularza polskiego wprowadził je Stanisław Konarski, kiedy dwa korpusy rosyjskie wybrały nam przedostatniego króla, czyli Augusta III). Wtedy rozpoczyna się pierwsze powstanie narodowe, czyli Konfederacja Dzikowska, 34 lata później następne: Konfederacja Barska. I w każdym z nich pojawiają się próby dotarcia do „kontrelit” w Imperium Rosyjskim: do poczucia zniewolenia samych Rosjan przez „germański” w swej istocie carat, albo do „żywiołu kozackiego” i jego

don 2001; J.H. Billington, Fire in the Minds of Men. Origins of the Revolutionary Faith, New York 1980. 
poczucia zniewolenia przez Petersburg. W każdym razie od XVIII w. zaczyna się polska „sytuacja rewolucyjna” - dojmujące poczucie zniewolenia zewnętrznego i wywołany tym podział w elitach polskiej peryferii rosyjskiego imperium. Część chce się bić o to, żeby już nie być peryferią - tylko odzyskać niepodległość. Oczywiście ta sytuacja dramatycznie nasila się z chwilą, kiedy Polska traci nie tylko niepodległość, ale samo państwo w roku 1795. Od razu mamy spiski, mamy konspirację - tu Faustyna Ciecierskiego, tam Joachima Deniskę. To nie zdarza się co 16 lat. Wskazując różne punkty na mapie Polski, można równocześnie wymieniać niemal bez przerwy jakieś konspiracje. Pewną cezurę, dłuższą przerwę wprowadzi rok 1864 (klęska powstania) i 1870 (klęska Francji). Potem te konspiracje wygasają na jakiś czas. To jest przyczynek do szczególnej roli powstania styczniowego, ale do powstania $1863 \mathrm{r}$. trudno wskazać okres, w którym nic się nie dzieje. Nawet w latach 1815-1830 niby spokojnym Królestwie Polskim reżimu wiedeńskiego - też są rozmaite konspiracje. Ale zostawmy to. Najważniejsza „sytuacja rewolucyjna", jaka występuje w przypadku Polski i decyduje o kolejnych powstaniach, bierze się ze zniewolenia, z braku wolności, co odczuwa część elit. Czy ona jest powszechna - to jest pytanie sporne, ale jest na tyle odczuwalna, że stanowi to problem polityczny - raz większy, raz mniejszy. Nigdy nie było tak, żeby 100 proc. elit było niewrażliwych na to zagadnienie. Jaka była sytuacja w latach pięćdziesiątych XIX w.? Dobrze opisał ją prof. Stefan Kieniewicz, zwracając uwagę na fakt, że w administracji Królestwa Polskiego mniej więcej na 10 tys. urzędników w spisie było około stu kilkudziesięciu Rosjan. Reszta to są Polacy. Tak to po prostu wyglądało. W korpusie oficerskim na terenie Królestwa Polskiego i ziem zabranych jest 30 do 40 proc., jak szacuje Djakow, katolików. To pokazuje, że stopień kolaboracji znacznej części elit peryferii z centrum - był duży. Jerzy Borejsza: Częściowo jednak i stopień akomodacji?

Andrzej Nowak: Nie, bo kolaboracja to czynna współpraca.

Maciej Janowski: Czy raczej to, o czym pisał Andreas Kappeler w swojej książce Rußland als Vielvölkerreich ${ }^{4}$, odnosząc się do dawnego modelu przednacjonalistycznego Imperium Rosyjskiego, które elity małoruskie inkorporowało do imperium, pozwalając im na zachowanie pewnej kulturowej odrębności? Byłby to szerszy model inkorporowania elit.

Andrzej Nowak: Tu mamy państwo polskie o długiej tradycji i wykształconej elicie.

Jerzy Borejsza: A stopień inkorporacji zależy również od wyznania.

${ }^{4}$ A. Keppeler, Rußland als Vielvölkerreich, München 1992. 
Andrzej Nowak: Trzeba uwzględnić tę sytuację narastającego, a w każdym razie dużego zaangażowania części elit w zarządzanie terenem dawnego państwa polskiego na rzecz władzy, której centrum znajduje się gdzie indziej. To jest wynikiem w dużej części terroru, jeśli mogę tak powiedzieć, a w każdym razie polityki bardzo twardej ręki prowadzonej przez Iwana Paskiewicza. Są oczywiście spiski: można szacować, że 4 tys. osób przewinęło się przez Cytadelę w ciągu pierwszych 20 lat jej istnienia, czyli do 1855 r. To nie jest dużo, bo potem będzie mniej więcej dziesięć razy tyle czy piętnaście. Są więc spiski, ale można powiedzieć, w Królestwie panuje „spokój i porządek” na poziomie dostrzeganym przez większość poddanych. Jednocześnie mamy emigrację - to bardzo ważny czynnik. Po prostu, nie byłoby powstania bez emigracji, bez Ludwika Mierosławskiego. Jerzy Borejsza: Bez Kamieńskiego, bez „Demokraty Polskiego”.

Andrzej Nowak: A przede wszystkim, bez Adama Mickiewicza i Juliusza Słowackiego, bez Fryderyka Chopina.

Jerzy Borejsza: Co do tego zgoda, z jednym post scriptum, że jeśli chodzi o Mickiewicza, i jeszcze paru tych, którzy rządzili duszami polskimi, to pozostawali oni w większości nieznani na Zachodzie. Natomiast tam znają Mierosławskiego i Charlesa Edmonda, czyli Karola Chojeckiego.

Maciej Janowski: Nie można powiedzieć, że Mickiewicz pozostawał nieznany w swoim pokoleniu w Europie, przypomnijmy, jak ważny był choćby dla Jules'a Micheleta.

Andrzej Nowak: Ich dzieła przypominają polskim elitom, że sprawa polskiej niepodległości jest ważna, że służba tej sprawie, jej uznanie, stanowi także ważny element prestiżu społecznego. Jeśli to odrzucamy, to możemy wystawić na szwank częściowo nasz prestiż w środowisku polskim. Zwrócił na to uwagę Henryk Wereszycki, ale i Kieniewicz o tym pisał, mianowicie oddziaływanie syndromu Targowicy w części elit społecznych. Emigracja przypominała - musimy powstawać.

Maciej Janowski: Duch Szczęsnego Potockiego zamykał Andrzejowi Zamoyskiemu drogę do ugody z carem, jak to ujął Wereszycki.

Andrzej Nowak: To jeden aspekt oddziaływania emigracji, a jest i drugi. To jest ta broszurka Józefa Pawlikowskiego Czy Polacy moga się wybićna niepodległość? ${ }^{5}$. I to stale powracające pytanie - jak to zrobić? Nie udało się w powstaniu listopadowym, potem nie było szans - Polacy byli sterroryzowani przez „żelazną rękawicę” Paskiewicza, ale to problemu nie usuwało, tylko odsuwało. Wtedy się nie udało powstać skutecznie, to może uda się jakoś inaczej? Jak się uda? Może właśnie poprzez masowe postaniem chłopskie przez połączenie sprawy społecznej ze sprawą narodową? Emigracja

\footnotetext{
${ }^{5}$ J. Pawlikowski, Czy Polacy moga się wybić na niepodległość?, Paryż 1800.
} 
przerobiła to na wiele sposobów, dostarczając tych sposobów do kraju, do części elit, kilkuset, kilku tysięcy, które słyszały, że są takie pomysły, projekty wystąpienia i że „musimy to zrobić”. Ostatecznie przychodzi moment kluczowy, czyli zelżenie nacisku w Polsce, wynikające z przegranej wojny krymskiej, oczywiście tutaj prof. Borejsza ma rację. Zelżenie przyjść musiało, to nie był jakiś błąd władz carskich - musiały złagodzić swoją politykę. Z różnych przyczyn, w tym przypadku z powodu niewydolności wewnętrznej aparatu, która ujawniła się w przypadku wojny krymskiej, nie jest tak, że władca państwa autorytarnego czy totalitarnego może w nieskończoność przedłużać najtwardszą wersję swoich rządów. Trzeba było coś zmienić. W dodatku wymogi polityki zewnętrznej - stawka na sojusz czy na porozumienie z Francją - miały ogromne znaczenie. Nie tylko w wymiarze międzynarodowej polityki, o którym panowie mówili, czyli kalkulacji geopolitycznej, że Francja wystąpi przeciwko Austrii, czyli przeciwko naszemu zaborcy, i że dołączy do tego (ze względu na konflikt interesów na Bałkanach) Rosja.W 1858-1859 r., kiedy Francja angażuje się militarnie przeciw Austrii i pomaga w zjednoczeniu Włoch, rosyjscy politycy rzeczywiście rozważali taki scenariusz: może teraz będzie okazja, żeby zemścić się na Austrii za jej dwulicowe (wobec Rosji) zachowanie w czasie wojny krymskiej, a przede wszystkim będzie okazja zrealizować odwieczny plan dominacji nad Bałkanami i otwarcia drogi na Stambuł? Aleksander II odrzucił ostatecznie tę pokusę jako zbyt niebezpieczną - ale ona była. Dla nas ważniejsze jest to, że Rosja - rozważając możliwość bliższej współpracy z Francją (także po to, by odsunąć ją od głównego wroga rosyjskich interesów imperialnych, czyli od Anglii i imperium brytyjskiego) i stając na krawędzi konfliktu z Austrią - dopuszczała wtedy pierwszy raz panslawizm jako swoją ideę oddziaływania na Bałkany. A czy można być „dobrym ojcem” wszystkich Słowian i rządzić tylko pałką Słowianami znad Wisły? To także był powód łagodzenia kursu polityki rosyjskiej wobec Królestwa Polskiego w końcu lat pięćdziesiątych.

Potrzebne było przełamanie wizerunku okrutnego prześladowcy Polski. Polska miała wtedy jeszcze nie najgorszą prasę w krajach słowiańskich: nie ma jeszcze stereotypu „Judasza Słowiańszczyzny”. On się pojawi dopiero po 1863 r. Trzeba było więc jakoś łagodzić ten kurs wobec Polski nie tylko ze względu na stosunki z Francją, co było oczywiście najważniejsze, ale ze względu na popularyzowanie sprawy rosyjskiej wśród ludów południowosłowiańskich. Część elit rosyjskich uważała, że jest możliwe porozumienie z Polską - i tu nie mówię o Aleksandrze Hercenie, ale o liberałach rosyjskich, tych kręgach, których widomym reprezentantem był wielki książę Konstanty. On reprezentował tę grupę, która miała także swoje „odnogi” na emigracji, że tak się wyrażę,jak Dołgorukow czy Kawielin, który wyjechał 
z Rosji rozmawiać z emigrantami, polskimi emigrantami także, sondując ich stanowisko. Tliła się, krótko mówiąc, nadzieja na jakieś porozumienie - damy wam jakąś autonomię w Królestwie, ale nic nie możecie dostać za granicą Bugu.

Jerzy Borejsza: Ktoś to ładnie zacytował Mikołaja Czernyszewskiego, że jak sobie popił w Petersburgu z tym całym polsko-rosyjskim towarzystwem, to powiedział - oczywiście, na wszystko zgoda, ale Litwy wam nie damy. To była sprawa granic Rzeczypospolitej.

Andrzej Nowak: Konstrukcja polegała na tym, że wtedy Królestwo Polskie miało być przykładem dobrych stosunków - dobrych z punktu widzenia Petersburga, tzn. takich, w których Polacy akceptują autonomię jako część imperium rosyjskiego, natomiast na terenie ziem zabranych, na wschód od Bugu następuje rusyfikacja, i to przyspieszona, bo taka jest dynamika procesów społecznych, narodowych, językowych, kulturowych w Europie Wschodniej. Czy taki wzór był do przyjęcia dla Polaków? Czy można było liczyć na więcej autonomii? Wtedy właśnie pojawił się z całą ostrością problem podziału w elicie. Elity widziały szansę żądania więcej: nie możemy już udawać, że niczego nie możemy żądać, że jesteśmy zadowoleni nie możemy, bo odzywa się wspomniane widmo Targowicy. Jednocześnie zmieniła się sprzyjająca sytuacja międzynarodowa - nie już Świętego Przymierza mocarstw rozbiorowych i jednocześnie narastała presja społeczna od dołu, presja uzasadniająca sens niepodległości. Podam jeden przykład „sytuacji rewolucyjnej” w Polsce i „paliwa” do niej. W powiecie piotrkowskim w latach 1833-1853 z 11 tys. rekrutów z tego powiatu wybranych do służby w armii rosyjskiej w głębi imperium - wróciło do domu 498. Reszta gdzieś zginęła czy umarłą na linii kaukaskiej czy orenburskiej. Nie tylko do elit, ale też do prostych ludzi dociera ten problem: służymy gdzieś, komuś obcemu daleko, co nie ma nic wspólnego z naszymi interesami, płacimy podatki. Żydzi płacą swoje podatki za rekrutów, też traktując tę władzę jako dalszą, to osobny problem asymilacji Żydów. W każdym razie mamy do czynienia z poczuciem obcości władzy, na społecznym „dole” także. To powoduje wzrastającą presję. Taka była dynamika wypadków, nikt tego nie zaplanował, nie kontrolował. Projekt ugody, kolaboracji elit peryferii z elitą (liberalną) centrum na nowych, lepszych warunkach - wali się w 1861 r. Nie chciał tego Aleksander Gorczakow, nie chcieli tego Polacy. Po prostu w takiej, a nie innej sytuacji doszło do takiego, a nie innego zachowania części elit, której symbolem jest Andrzej Zamoyski, jak Pan profesor to przypomniał za Wereszyckim. Ostatnią deską ratunku dla Rosji stał się Wielopolski, ale okazało się, że Wielopolski może za sobą pociągnąć zbyt małą część społecznych elit, żeby uratować projekt ugody. To jest już dramat doskonale opisywany przez wspomnianą 
powyżej koncepcję Galtunga: kiedy elita peryferii przestaje współpracować w sposób efektywny z elitą centrum - wtedy nieuchronnie pojawia się kryzys imperium, „sytuacja rewolucyjna” dojrzewa do powstania, do rewolucji.

Maciej Janowski: Mam wrażenie, że prof. Nowak podchodzi do problemu podobnie jak prof. Zdrada - poprzez podkreślenie długofalowego procesu, który w pewien sposób obiektywizuje się, działając samą wewnętrzną logiką niezależnie od motywacji indywidualnych osób, które w danym momencie występują, i że ten proces wynika z ogólnych procesów przemian imperiów. Czy można powiedzieć że bierze się z nacjonalizacji imperium? Chodzi mi o to, że Imperium Rosyjskie już przed powstaniem powoli odchodzi od takiego tradycyjnego modelu imperium przednarodowego, jesli można się tak wyrazić - „przezroczystego" pod względem narodowym (choć oczywiście nigdy nim nie było w stu procentach).

Andrzej Nowak: Imperium Rosyjskie nie mogło być imperium przednowoczesnym, od kiedy dokonał się trzeci rozbiór, a zwłaszcza od momentu, kiedy pod berło Romanowów dołączone zostało jeszcze w 1815 r. Królestwo Kongresowe złożone z ziem wcześniejszego zaboru pruskiego i austriackiego. Po prostu skoro więcej ludzi w tym imperium umiało wtedy pisać i czytać po polsku niż po rosyjsku, liczniejsze były elity wykształcone w kulturze polskiej niż rosyjskiej. To nie mogło się inaczej skończyć niż jak Ausgleichem (podziałem imperium na część polską i rosyjską), na który absolutnie nie były gotowe elity rosyjskie (od Mikołaja Karamzina do dekabrystów, którzy także - jeśli w ogóle uznawali możliwość niepodległości Polski, to najwyżej w granicach Królestwa Kongresowego). Nie dający się usunąć z Imperium problem zbyt licznej, zbyt świadomej polskiej elity i dojrzewającego w jej kręgu programu narodowego uruchamiał swoim przykładem kolejne projekty narodowe (potem ukraiński, litewski, gruziński, fiński, itd.), a zarazem - nacjonalizm rosyjskiego centrum. To prowadzić musiało do wybuchu.

Jerzy Zdrada: Karamzin mówił - od granicy Bugu wszystko jest nasze.

Andrzej Nowak: Dodajmy, że elity miały poczucie narodowe już w XVIII w., teraz zaś także i doły społeczne zaczęły odczuwać obcość władzy zewnętrznej i naciskać na te elity, popychając je do działania.

\section{Problem romantyzmu}

Maciej Janowski: Na jeszcze jedną kwestię chciałbym zwrócić uwagę. Chodzi mi o polski romantyzm. Romantyczny światopogląd (Mickiewiczowski i inny) daje pewien rodzaj okularów do patrzenia na kwestie społecz- 
ne i narodowościowe, w tym również na perspektywy sukcesu czy klęski powstań.

Andrzej Nowak: Jak najbardziej podkreślam znaczenie romantyzmu, czy bardziej emigracji jako ważnego ośrodka opiniotwórczego wpływającego na część elit w kraju, ale na pewno nie zgadzałbym się z taką interpretacją, że romantyzm wytworzył jakieś okulary, przez które widziano w fałszywy sposób rzeczywistość. Nie. Rzeczywistość taka była - polegała na zniewoleniu Polski, na zagrożeniu wynarodowieniem, czego przykładem była między innymi masowa służba elit na rzecz obcych państw. Tylko że w innych państwach już po 1860 r. można było, w Galicji na przykład, uzyskać pewne koncesje i mieć nadzieje na ich utrwalenie. Tam powstania nie było.

Maciej Janowski: Chciałbym wrócić na chwilę do romantycznych okularów. Mnie nie chodziło o to, czy te okulary były fałszywe czy prawdziwe (tzn. ja osobiście uważam, że były fałszywe, ale nie o to mi teraz chodzi). Chodzi mi o to, że istnieje zawsze coś takiego, jak Zeitgeist: każda epoka, czy romantyzm, czy pozytywizm popowstaniowy, czy neoromantyzm z początku XX w. tworzy swoje okulary, czyli swoistą perspektywę rozumienia i oceny rzeczywistości. $W$ jakiej mierze są one prawdziwe czy fałszywe możemy rozmawiać, ale to nie powinno nam przeszkadzać w dostrzeżeniu, że owe okulary, takie czy inne, są zawsze. Patrzymy na świat przez kategorie naszej epoki. Polityk, nawet zawodowy, któremu się wydaje, że jest cyniczny i makiawelski, też jest przez te idee współuformowany i szanse swojej polityki ocenia, żyjąc w swojej kulturze i środowisku. To miałem na myśli, mówiąc o kulturowej atmosferze, powodującej, że pewne rzeczy się widzi tak, a nie inaczej. Byłoby ciekawe zrekonstruowanie różnic między tymi perspektywami, ale to materiał na inną dyskusję.

Andrzej Nowak: Mówię na wszelki wypadek, że te romantyczne okulary ukazywały w tym przypadku rzeczywistą sytuację.

Jerzy Borejsza: Uważam, że nie należy przesadzać z romantycznymi okularami. Romantyzm tak, ale my rozciągamy przez fakt wybuchu powstania styczniowego to patrzenie na zbyt długi okres. Tymczasem wystarczy zajrzeć do ostatnich mów księcia Adama Czartoryskiego, żeby zobaczyć, że wniosek, jaki wyciągał po wojnie krymskiej, i on jest sformułowany w jego przemówieniach, sprowadza się do hasła pracy organicznej. To właśnie w ostatnich latach życia zalecał rodakom.

Jerzy Zdrada: Otóż tak się jakoś utarło, zwłaszcza w jakiejś nowszej polskiej historiografii, że romantyzm to było polskie nieszczęście. Że ten romantyzm spowodował wyskok nieszczęśliwy, jakim było powstanie styczniowe. To stwierdzenie jest wręcz ahistoryczne i wynikające z pewnej 
zaściankowości, jeśli można użyć tego słowa, patrzenia na romantyzm. Gdyby się porównało, jakie były motywacje romantyczne ruchów innych, choćby i włoskiego, to być może okazałoby się, że w Polsce nie było aż tak źle. Niektórzy stempel romantyzmu przybijają na wszystko. Jeden przykład: egzaltacja niemiecka a egzaltacja polska. Polacy wychodzą na tle egzaltacji niemieckiej jako zimni, wyrachowani, dobrze wiedzący. Oczywiście można się było podpierać cytatem, jak trzeba było, z Mickiewicza, Słowackiego, Krasińskiego, zależało od tego, kto to robił - we dworze, czy na poddaszu, ale używano tego w moim przekonaniu znacznie bardziej racjonalnie niż gdzie indziej. A gdzie indziej tych nieszczęść się nie dostrzega, tylko się uważa, że były one czymś bardzo wzniosłym. Chociażby 1813 r.w Niemczech.

Maciej Janowski: Bo rok 1813 się w Niemczech udał. Gdyby Napoleon ich pobił, to by była zupełnie inna historia.

Andrzej Nowak: Dlaczego się nie udał w Polsce? Przez romantyzm?

Jerzy Zdrada: Jak chcemy badać historię, to nie możemy jej badać z nastawieniem, że skoro się coś nie udało, to było od samego początku poronione. Udział polski w elitach zarządzających państwem, czy to w Królestwie, czy nawet na ziemiach zabranych, w części przynajmniej administracji, czy w armii rosyjskiej - to wszystko są rachunki czy szacunki trafne, z jedną, ale za to zasadniczą korektą. Na jakich stanowiskach? Gdzie? Owszem, na wszystkich podrzędnych stanowiskach byli Polacy, bo nie było Rosjan, natomiast na wszystkich ważniejszych, byli wyłącznie Rosjanie. Jeżeli mówimy o Polakach w administracji na ziemiach zabranych, tonie zapominajmy o samorządzie szlacheckim. On właściwie w powstaniu styczniowym już się nie odrodził w takiej formie. Czy on miał jakieś uprawnienia? Nie, ale była pewna tradycja, która decydowała, że się szło do pana marszałka powiatowego rozsądzać na przykład spory majątkowe. Ale to jednak jest administrowanie. Od prystawów począwszy, starano się wybierać ludzi absolutnie lojalnych. Część z nich zawiodła tę lojalność w czasie powstania styczniowego, dlatego potem Michaił Murawjow i inni powiedzieli: „Wyrzucić wszystkich!”. To istotny element, który się wiąże z tym, co mówiłem o własnym państwie. Stanowiska podrzędne mogą być obsadzone w znacznym procencie, a proszę policzyć, ile procent Polaków było w administracji Generalnego Gubernatorstwa? Czy to były rządy polskie? Porównanie dwóch epok nie całkiem uprawnione, ale ono daje coś do myślenia. Otóż autonomię daną Wielopolskiemu car opatrzył warunkami. Warunki są znane mniej więcej od stu lat, bo przynajmniej część listów do wielkiego księcia Konstantego była publikowana jeszcze w XIX w., bo potrzebowano tego do podkreślenia, że ten car bardzo dbał o rosyjskie interesy w Priwislanskim Kraju. Dobrze - powiedział car - autonomia administracyjna 
(przez którą rozumiano szkolnictwo i inne rzeczy, bardzo ważne, rzecz jasna, ale bez konstytucji, bez marzenia o czym innym, z urzędami dla Polaków, ale bez wykluczenia Rosjan). To jest wyraźnie napisane w czerwcu 1862 r., kiedy Wielopolski z triumfem wrócił. Czy Wielopolski o tym wiedział? Może nie. Jeżeli nie wiedział i nie umiał się domyśleć i sądził, że pełna władza jest w jego ręku, to się mylił. Aleksander pisze również do Konstantego bardzo ważny list - „Nie dowierzaj Wielopolskiemu”. Trzeba go pilnować, żeby nie podskoczył za dużo. Czytając i analizując te dokumenty, które są znane, które były po wojnie opublikowane, chociażby jeszcze raz w korespondencji namiestników, a także niektóre dokumenty znane już wcześniej, widzi się, o co Rosjanom w ogóle chodziło. Teraz od tych przypomnień chciałbym przejść do rzeczy, która jakoś umyka. Ciągle mówimy o odpowiedzialności za powstanie - a to romantyzmu, a to emigracji, a to jakichś niedowarzonych młokosów, którzy wyszli spod rózgi rodzicielskiej, jak pisał Walery Przyborowski, sam zresztą powstaniec, itd. Jakoś nie widziałem nigdzie porządnej analizy mówiącej o odpowiedzialności strony rosyjskiej za wybuch powstania, w moim przekonaniu ciężkiej odpowiedzialności politycznej.

Maciej Janowski: Ona jest zasadnicza. Prof. Nowak powiedział, że gdyby nie było rozbiorów...

Jerzy Zdrada: Nie o tę generalną odpowiedzialność chodzi. Odpowiedzialność w tym konkretnym wypadku i konkretnym momencie historycznym, który, jak niektórzy mówią, mógł się rozwinąć w różny sposób. Gdyby nie było hasła powstania, to Wielopolski kontynuowałby swą politykę. Tylko że zanim Wielopolski ewentualnie mógł w konkurencji z czerwonymi walczyć o rząd dusz, to było poprzednie sześć lat. Sześć lat! Równo od czerwca 1856 r. do czerwca 1862 r. Aleksander II przyjechał do Warszawy i Jedlicki tu pisze, jak go wszyscy witali, cytuje list Józefa Kajetana Janowskiego, który napisał świetne pamiętniki (o tych pamiętnikach jeszcze będzie okazja coś wspomnieć). Otóż był witany z nadzieją. Ludzie czekali - wszystko to jest prawda.

Maciej Janowski: Powiedział „Point de rêveries, messieurs”, prawda? Jerzy Zdrada: Tak, z jedną tylko uwagą. Na co czekali? Nie na króla polskiego, in spe, bo nie był koronowany, ale taki tytuł nosił, jak przypomina Jedlicki. Oni czekali na przełom. Dlatego że we wszystkich pamiętnikach i różnych relacjach, jakie znam, śmierć Mikołaja została przyjęta jako śmierć tego, który uosabiał najgorszy system. Rosjanie odczuwali tak samo - są takie relacje zarówno rosyjskie, jak i polskie. Przecież ta śmierć była przyjmowana jako zamknięcie najgorszego okresu, po którym może być już tylko lepiej. Doradcy Aleksandra doskonale wiedzieli, że część polskich elit szykuje się, żeby mu coś powiedzieć na temat tego, co tu 
powinno być w Królestwie i car rzekł im to, co Pan powiedział - „Żadnych marzeń, panowie". Żeby to raz! Dwa razy. Tylko ciągle się zapomina, kto mu to podsunął. Przecież Aleksander nie sam z siebie pewne rzeczy mówił. Kto mu to podpowiedział? Aleksander Gorczakow, minister spraw zagranicznych! Ten, który liczył na sojusz z Francją po to, aby otworzyć Morze Czarne dla zbrojeń rosyjskich. To Gorczakow, liberalny, traktowany przez część naszej historiografii jako ten, który był jeśli nie propolski, to w każdym razie przynajmniej nie krwiożerczy, w żadnym wypadku. Gorczakow, wielki dyplomata, którego wszyscy chwalą, zrobił rzecz, która się zemściła również na stosunkach polsko-rosyjskich, bo wtedy pojawiła się szansa, aby dając coś, przechwycić rząd dusz. To wtedy była szansa, nie po pięciu ofiarach, ani tym bardziej po masakrze. Wtedy była szansa, bo Rosja Aleksandra nie była jeszcze na Zachodzie skompromitowana, bo z nią i w Rosji, i w Polsce łączono pewne nadzieje i tutaj gdyby bodaj wrócono do Statutu Organicznego, to wtedy - jestem przekonany, elity polskie poparłyby kurs poprawy stosunków z Rosją, unikając obciążeń zarzutami o targowiczenie.

Andrzej Nowak: Votum separatum. To jest piękne założenie, że Rosja w 1856 r. jest białą, zgotowaną do zapisania kartą. Aleksander był człowiekiem dojrzałym, trzydziestoparoletnim i jak się przeczyta jego korespondencję do objęcia tronu i po objęciu tronu, to widać, że on jest tym samym człowiekiem, myśli tymi samymi kategoriami. Wolności Polakom nie dawać - te słowa testamentu Mikołaja są wiernie zapamiętane.

Jerzy Zdrada: Wiem o tym. Natomiast jeśli mówimy o odpowiedzialności, widzieć musimy tu dwie strony politycznego dyskursu, polską i rosyjską. Maciej Janowski: Nie ma chyba w polskiej nauce, bo niekoniecznie w publicystyce, idealizowania polityki rosyjskiej tego czasu.

Jerzy Zdrada: Gdy doszło do manifestacji na Placu Zamkowym i pierwszych pięciu ofiar, to pierwsze pytanie Aleksandra było, czy Warszawa została zbombardowana z Cytadeli. O odpowiedzialności Rosji za nakręcanie atmosfery, która doprowadziła do powstania, wolałbym więc nie zapominać. Nadto Rosja wiedziała od początku, a po powstaniu listopadowym tym bardziej o tym pamiętano, że nie można dopuścić Polaków do żadnych wyższych stanowisk. Tu był szlaban zdecydowany.

Jerzy Borejsza: Ależ Polaków dopuszczono do wyższych stanowisk, i to nawet jeszcze po powstaniu styczniowym. Tylko nie w Priwislinskom Kraje. Na Syberii, w Kazaniu, byle dalej od ziem polskich. A iluż Polaków dowodziło wojskami rosyjskimi podczas wojny z Turcją w latach 1877-1878! 


\section{(Nie)możliwość ugody}

Maciej Janowski: Co do odpowiedzialności Rosji, to chyba całkowicie oczywiste. Nikt chyba poważnie nie mówił, że Rosjanie z dobrą wolą ofiarowali kompromis.

Andrzej Nowak: W 1963 r. bardzo wyraźnie i dobitnie powiedział to Stanisław Stomma: Rosja chciała kompromisu, który Polacy odrzucili ${ }^{6}$. Dziś powtarzają to niektórzy publicyści.

Maciej Janowski: Wyszła przed samą Wiosną Ludów w Austrii taka książka o kwestii narodowej w monarchii, której tytuł jest wspaniały: Sibyllinische Bücher aus Österreich ${ }^{7}$. Historia prób kompromisów narodowościowych w XIX w. jest historią ksiąg Sybillińskich - oferuje się w danym momencie coś, co już nie wystarcza, ale gdyby pięć lat wcześniej zostało zaoferowane, mogłoby być przełomem. Staram się nie być deterministą historycznym, widzieć różne możliwości rozwoju, tak samo jak dziś myślę, że przyszłość jest otwarta i różne rzeczy mogą się wydarzyć - mam więc poczucie, że muszę logicznie przenieść to myślenie również na minione epoki i uważać, że w każdym danym momencie historycznym są rozmaite możliwości.

Mówiąc konkretniej - inaczej niż prof. Nowak i prof. Zdrada widzę generalną dynamikę ruchów narodowych w XIX w. Nie jestem przekonany, że dążenie do nacjonalizacji, do konfliktu lokalnych elit z władzami imperialnymi i do zaostrzania tych konfliktów, a w efekcie do budowy państw narodowych, jest w XIX w. mechanizmem dominującym. Najbardziej nowoczesna struktura ówczesnego świata, za jaką wszyscy uważają Imperium Brytyjskie, to są przecież w istocie takie duże Austro-Węgry $\mathrm{z}$ ideą indirect rule, $\mathrm{z}$ dopuszczaniem lokalnych elit do funkcjonowania w systemie władzy. My wiemy ex post, że to się zawaliło kilkadziesiąt lat później, ale przecież wtedy nikomu to by nie przyszło do głowy. W XIX w. istnieje otwarte przez cały wiek napięcie między globalizacją a partykularyzacją - i nigdy do końca nie wiadomo, jak się ono zakończy. Można zrobić antologię dziewiętnastowiecznych tekstów o tym, jak przestarzałe są państwa wielonarodowościowe, ale można też zrobić drugą antologię tekstów o tym, że wymogiem nowoczesnej cywilizacji jest budowa coraz większych państw (sądzili austriaccy socjaldemokraci, że narodowość stanie się jak religia kwestią nieterytorialną, kwestią indywidualnych wyborów). Mnie się zawsze wydaje, że właśnie dlatego wiek XIX jest dla historyka tak ciekawy, że ten spór aż do 1914 r. jest nierozstrzygnięty.

\footnotetext{
${ }^{6}$ S. Stomma, Z kurzem krwi bratniej, ,,Tygodnik Powszechny”, nr 3, 1963.

7 [K. Möring], Sibyllinische Bücher aus Östreich, Hamburg 1848.
} 
Dopiero I wojna światowa w pewien sposób rozstrzyga to na korzyść państw narodowych, na jak długo - zobaczymy. Tak więc obraz nieuchronnego narastania konfliktu polsko-rosyjskiego niezbyt mnie przekonuje. Dążenie do budowy odrębnych państw narodowych istnieje, ale jego roli nie można absolutyzować, również przy badaniach wzajemnych stosunków Polski i jej zaborców.

Jerzy Borejsza: U carskiego ministra wojny Dmitrija Milutina w jego dniewnikach, czyli dziennikach jest wiele o Wielopolskim. Milutin wylicza, ile osób popiera Wielopolskiego w momencie, kiedy on jedzie do Warszawy i ile jest przeciwnych. Robi zestawienie i z zestawienia wychodzą rzeczy piękne, wynika, że on ma ogromne poparcie w Petersburgu. To jedyny człowiek, którego się obawia wśród Polaków Otto von Bismarck, o tym pisałem. Stanisław Stomma zaś jest zbyt kategoryczny w obronie Wielopolskiego i jego szans, w pisaniu, że powstanie nie miało szans.

Andrzej Nowak: Napisał wyraźnie, że Rosja była jedynym zaborcą, który oferował kompromis Polsce. Jedynym.

Jerzy Borejsza: Trudno jednak powiedzieć, żeby Stomma był specjalnym chwalcą Rosji. Nie podzielam jego poglądów, ale nie o to chodzi. To jedna uwaga. Druga uwaga natomiast na temat szans powstania, o które się nie będziemy spierać, bo to nie ma sensu. Na przykład Garibaldi uważał, że powstanie nie ma żadnych szans i on wysłał tego biednego Francesca Nullo i spółkę, żeby zamanifestować współczucie dla Polaków, jedność z Polakami. Po prostu wiele osób - Polaków i nie tylko - uważało ówcześnie, że powstanie nie ma szans. Jak patrzę na to, kto z cudzoziemców polityków się obawiał powstania, to powstania obawiał się poza ludźmi z Petersburga przede wszystkim Bismarck. Dokładnie rzecz ujmując - bał się Wielopolskiego i tego, że nie dojdzie do powstania. Bismarck bowiem życzył sobie powstania i nie życzył sobie zbliżenia polsko-rosyjskiego.

\section{Sprawy narodowościowe}

Maciej Janowski: Przejdźmy do kwestii odbudowy Rzeczypospolitej. Jak sobie wyobrażano przyszłą Polskę? Granice z 1772 r. wydaje się, że są takim mocnym punktem odniesienia, a co ma być w tych granicach? Czy ta trialistyczna pieczątka coś podpowiada?

Jerzy Zdrada: To jest ważny symbol, z tym, że żeby była sprawa jasna, granica z 1772 r. była ideą postulowaną. Powstanie o taką granicę nie walczyło. Musimy o tym pamiętać. Były np. pomysły, że jak się wciągnie Austrię z Francją, to Galicja zostanie wymieniona.

Maciej Janowski: Na Mołdawię i Wołoszczyznę.

Jerzy Zdrada: Tak, pojawiały różne takie pomysły, w zależności od sytua- 
cji międzynarodowej. Natomiast panowało przekonanie i taka dyrektywa została wysunięta w Paryżu (potem się zaczęto zastanawiać, kto ją naprawdę wypowiedział), że granica krwi rozlanej w zaborze rosyjskim wytyczy granicę Polski. Dlatego były Horki czy Sołowiówka, żeby pokazać, że mamy tam do tego historyczne prawa, ale i polityczne, bo o to walczymy. To potwierdzała ta słynna pieczęć trójherbowa - będzie Polska, ale już nie w unii Polski z Litwą, jak to przedstawiano jeszcze na pieczęciach powstania listopadowego, tylko już również z Rusią. Czy za tym stała bardzo jasno sformułowana koncepcja odnośnie do organizacji państwa i tego, czym ono ma być - to już sprawa mniej jasna. Mówiono o wolności dla wszystkich - nawet jeszcze Komitet Centralny Narodowy i manifesty oraz dekrety Rządu Narodowego mówiły, że wszystkim na całym terytorium będzie dana wolność - językowa, religijna itd. Natomiast nie było mowy o tym, jaka będzie struktura wewnętrzna państwa. Szczerze mówiąc, chyba słusznie o tym nie mówiono. Ujawniły się pewne problemy.W łonie samej organizacji czerwonych, choćby między ludźmi kierującymi organizacją na Litwie i to wszystko jedno, czy to była ta bardziej czerwona, czy bardziej biała, a centralą warszawską. Z czego niektórzy wyciągają wniosek, że to był separatyzm litewski w rozumieniu historycznym Wielkiego Księstwa Litewskiego.

Jerzy Borejsza: Można mówić o pewnym separatyzmie nie tyle litewskim, ile powstańców z ziem dawnego WKL. Na emigracji po roku 1864 powstaje Delegacja Litewska czy towarzystwo „Żelmuo”. Ale jest to separatyzm ziomkostwa, a nie ojczyzn.

Jerzy Zdrada: Ja mówię o stosunkach we władzach powstańczych, czyli tych, które kierowały powstaniem i ewentualnie po zdobyciu władzy mogłyby tym państwem zarządzać czy kierować. To podkreślanie separatyzmu jest trochę na wyrost, bo to był separatyzm bezpośrednio w stosunku do decyzji Warszawy, tego, co trzeba było robić, a chyba nadinterpretacją jest idea odrębnego państwa po ewentualnym pokonaniu zaborców. To było i jest potrzebne Litwinom i Białorusinom dla podkreślenia swojej genealogii, do tego się trochę przyznają oficjalne środowiska na Litwie, a na Białorusi opozycyjne. Powstanie zostało wywołane pod hasłami republikański$\mathrm{mi}$ i to jest jasne. Natomiast czy gdyby doszło do interwencji i warunkiem powstania państwa byłaby korona dla jakiegoś Habsburga, to by tego nie zaakceptowano? Pewnie by zaakceptowano, tak jak w 1831 r. myślano o takim rozwiązaniu, żeby któreś z mocarstw zewnętrznych zachęcić do akcji na rzecz Polski. Ta sprawa była dalej otwarta. Natomiast zasadniczych trudności przysparzał stosunek do aspiracji narodowych tych ludów, że tak powiem, kresowych Rzeczypospolitej, zwłaszcza Ukraińców, czyli Rusinów. Dlaczego? Dlatego, że ten problem już bardzo ostro istniał w Galicji jako problem polityczny i państwowy. Żądanie podziału Galicji 
miało charakter żądania quasi-autonomii państwowej. Od lat pięćdziesiątych w Kijowie istniał już ruch z Antonowyczem na czele i wspólne drogi z tymi Polakami, którzy mówili o Rusi, a nie o Małorosji, rozeszły się. $\mathrm{Na}$ drugim miejscu stawiałbym kwestię Litwy etnicznej, która jeszcze wtedy takiej zdecydowanej odrębności od Polaków w tej walce nie manifestowała. Ludność tamtejszą połączyła jedna sprawa - mianowicie katolicyzm. Dopiero na trzecim miejscu bym w tym kontekście stawiał Konstantego Kalinowskiego, ale on nie uosabiał wszystkiego, tam jeszcze był Marcinkiewicz. W Mińsku na przykład manifestowanie odrębności inaczej się odbywało niż w Grodnie. Ten problem się narodził, a rozwinął się dopiero po powstaniu, w dużym stopniu wskutek polskiej klęski. Przybrał charakter ruchu antypolskiego. Mówi się, że Polacy w XIX w. na Wschodzie tracili autorytet wśród miejscowej ludności, bo każda klęska tam oznaczała upadek autorytetu Polaka, czyli pana i tradycji polskiej.

Maciej Janowski: Przemiany społeczne także odgrywały tu rolę. W Czechach Niemcy czescy tracili swoją pozycję w ciągu drugiej połowy XIX i pierwszych lat XX w., nie ponosząc (do 1918 r.) żadnych klęsk o charakterze polityczno-wojskowym.

Jerzy Zdrada: Zgoda. Ale powstania z całą pewnością były za każdym razem cezurą dostrzegalną. Problem narodowy to nie jest tylko sprawa polsko-tamtejsza, tych „tutejszych” jak na Białorusi. To jest również rozgrywka między Polakami a Rosjanami o to, kto tam będzie rządził. Rosjanie obawiali się tych słabych, uciemiężonych Polaków. Mało kto wie, że pierwsze pomysły czystki etnicznej, jak byśmy dziś powiedzieli, w trzech guberniach podległych generałowi-gubernatorowi litewskiemu Władimirowi Nazimowowi, wtedy jeszcze łagodnemu, który w polskich pamiętnikach szlacheckich ma opinię bardzo przystępnego i sprzyjającego Polakom (bo po nim przyszedł Murawjow) pojawiały się w jego otoczeniu. Z jego podpisem wyszły projekty wysiedlenia do Królestwa Polaków, którzy się buntowali, czyli jakieś adresy pisali, a to szkoły żądali, a to uniwersytetu, a to chłopów chcieli uczyć - a więc byli elementem wrogim. Wałujew, który je dostał, odpowiedział negatywnie. Dopiero Murawjow wprowadzał to wtedy innymi metodami. Na ten problem - Polacy a inne narody w ramach przyszłego państwa polskiego - trzeba patrzeć również jako na problem walki między interesami polskimi a interesami rosyjskimi.Czy myśmy mogli reprezentować lepiej interesy tych narodów? W moim przekonaniu jednak mimo wszystko tak. Dlatego że niepodległa Polska byłaby zbudowana - mówiąc ogólnie - w oparciu o system europejskiej kultury politycznej, czyli tej kultury, która szanuje przedstawicielstwo, reprezentację, wybory.Czy nie narzucałaby swojej kultury tym innym, niepolskim narodowościom? Pewnie tak, tak jak to robiły wszystkie narody. 
Maciej Janowski: Trochę boję się, że ewentualna niepodległa Polska po 1863 r. wcielałaby w życie model węgierski, gdzie ta sama szlachta, która przed 1848 r. wszystko by dała za samorząd komitacki, decentralizację, po 1867 r. zaczęła budować państwo jakobińskiego typu francuskiego zbiurokratyzowane, dążące do wynarodowienia mniejszości, do niwelacji różnic regionalnych itp.

Jerzy Zdrada: Tego oczywiście nie wiemy. Możemy tak przypuszczać, choć wiele wypowiedzi ówczesnych polskich wskazuje, że wcale w tym kierunku nie chciano iść. Ale praktyka po zdobyciu władzy bywa inna.

Andrzej Nowak: Nawiązując do uwagi prof. Zdrady, ,co by było, gdyby...”. Tutaj znów podkreśliłbym rolę emigracji jako laboratorium tych wszystkich koncepcji, o które Pan pyta - w tym przypadku koncepcji rozwiązania kwestii narodowej czy narodowościowej. Wiadomo, były one różne. Towarzystwo Demokratyczne Polskie na pewno by taką właśnie wizję reprezentowało, o której mówił Pan profesor, tzn.jakobińską, nacjonalistyczną.

Maciej Janowski: Nie endecką, ale demokratycznie-nacjonalistyczną.

Andrzej Nowak: Ale nacjonalizm byłby jej składową, podobnie jak centralizm. Silne było jednak też to skrzydło konserwatywne - czy konserwatywno-niepodległościowe, czy konserwatywno-liberalne - które reprezentował obóz Czartoryskiego. On sam przede wszystkim, ale i Hipolit Terlecki, Michał Czajkowski, Ksawery Sabbatyn, cała grupa ludzi, którzy pisali, że Ukraina jest czymś innym, odrębnym, że nie może już być tylko taką doczepką do Litwy w państwie, które zostanie odbudowane, że ma swoje silne tradycje. Innym elementem wpływającym na rozumienie tej kwestii są kółka w Kijowie, Żytomierzu, gdzie Polacy w latach pięćdziesiątych obcowali z rodzącymi się elitami ukraińskimi. Tu są chyba razem źródła, które spotykają się w koncepcji powstania, jaką wyraża odezwa Komitetu Centralnego Narodowego jeszcze sprzed stycznia 1863 r. Głosiła ona, że najpierw musimy pokonać wspólnego wroga, a jak go pokonamy, to wtedy możemy się podzielić (na Polskę, Litwę, Ukrainę). Nie kładziono nacisku na odtworzenie wspólnoty w granicach z 1772 r., tylko przekonywano, że to byłoby najlepsze rozwiązanie, ale jeśli nad Dnieprem zechcą pójść swoją drogą, to niech idą, tylko pokonajmy najpierw wspólnego wroga. Bardzo ciekawie pisał o tym w „Prawdzie” Kamieński, cieszył się z powstania Sejmu Krajowego w Galicji i tego, że Rusini mają tam swój głos - że będzie to forum, na którym polskie i ruskie racje będą mogły się spotkać i tam będzie można przekonywać Rusinów do zgody z Polakami. Ale jak nie zechcą, to nie musza być z nami, mogą pójść swoją drogą i wtedy przekonają się, co będzie dla nich lepsze. Nie był to więc program bezwarunkowego wcielenia Rusi do Polski w powstaniu styczniowym. Bardzo ważna obok 
sprawy narodów wschodnich jest kwestia żydowska. Niezmiernie ciekawa jednocześnie, bo przecież w patriotycznych broszurkach w okolicy pięćdziesiątej rocznicy powstania (a więc tuż przed I wojną) pisano, że udział w powstaniu, w ruchu patriotycznym polskim - był „polską drogą do asymilacji”, zupełnie inną niż np. niemiecka. Pisał o tym m.in. Bertold Merwin.

Maciej Janowski: Maria Janion do tego niedawno wróciła w książce Bohater, spisek, śmierć.

Andrzej Nowak: Ciekawe, że ta polska idea patriotyczna oczywiście nie oddziałuje szerzej na przyszłych Ukraińców, Białorusinów i Litwinów, natomiast u Żydów, w części elit żydowskich, oddziaływanie owej idei wzmacnia się maksymalnie w okolicy rewolucji moralnej i powstania styczniowego, prowadząc nie tak znowu małą grupę owych elit w stronę polskości. To właśnie zbliżenie spowodowane ideałami wzniosłymi, romantycznymi, które reprezentuje tradycja polska i Maraton Kornela Ujejskiego. Nie zapomnę, jak arcysympatyczny syjonista Rafael Scharf recytował mi w 1995 r. cały Maraton (w 1939 r. wyjechał do Izraela, a to była jego formacyjna lektura). Bardzo długi poemat, którego wymowa jest jednoznacznie narodotwórcza, wykorzystująca patos obrony przed zniewoleniem do budowania wspólnoty.

Jerzy Zdrada: Jedna uwaga. Rusini i Litwini mieli własne terytorium, Żydzi nie.

Andrzej Nowak: A Żydzi mieli bardziej rozwinięte elity.

Jerzy Borejsza: To prawda, że polskie powstania w nurcie europejskich walk narodowo-wyzwoleńczych były znaczące, ale głównym czynnikiem wpływającym na rozwój owego nurtu w Europie były kolejne rewolucje francuskie - w liczbie mnogiej. To ich przykłady oddziaływały, za nimi szliśmy my i inni.

Andrzej Nowak: We wschodniej Europie my stanowiliśmy jednak przykład dla innych. To było tu ważne.

Maciej Janowski: Jarosław Hrycak bardzo to podkreślał.

Jerzy Borejsza: Mam krzyż bity na rozkaz Traugutta, na którym widnieją razem herby Polski, Litwy i Rusi.

Andrzej Nowak: Teraz produkuje się je masowo.

Jerzy Zdrada: Można je kupić na targu we Lwowie.

Jerzy Borejsza: Czyżby z połączonymi herbami? Mam oryginał zatarty już bardzo. Cyrylicą jest napis „Bože spasi tvoi lûdi svaboda - ravienstvo niezavisimost”. Niezavisimost jest zamiast fraternité. Dla ziem białoruskich bito go już jesienią 1863 r., co świadczyło o istnieniu zapotrzebowania.

${ }^{8}$ M. Janion, Bohater, spisek, śmierć. Wykłady żydowskie, Warszawa 2009. 
Druga moja uwaga dotyczy kwestii ukraińskiej, czy też rusińskiej. Kiedy w roku 1867 Jarosław Dąbrowski się zirytował, to napisał list do obywatela Bednarczyka, w którym postulował zrozumienie, że rodzi się naród ukraiński. Reakcje na ten list do obywatela Bednarczyka w prasie ówczesnej, w „Głosie Wolnym”, który był takim ciągiem dalszym „Demokraty Polskiego", były unisono nieprzychylne. Wszyscy się rzucili na Dąbrowskiego - jacy tam Ukraińcy? Jakie państwo ukraińskie? Cała emigracja popowstaniowa runęła na niego i nie pamiętam, żeby go ktoś bronił. Był raczej osamotniony.

Jerzy Zdrada: À propos tych napaści. Dyskusja była dłuższa, bo dotyczyła stosunku do Ukraińców niejakiego Borkowskiego w Sejmie Galicyjskim. Natomiast co do takich pism, jak „Głos Wolny”, „Wytrwałość”, jest jeden wstydliwy problem z ich krytyką powstania i innymi tego rodzaju wypowiedziami. Mianowicie te dwa pisma i jeszcze parę innych, ale te dwa zdecydowanie, były infiltrowane i przez Juliana Bałaszewicza-Potockiego, i przez Apolla Belinę-Młochowskiego. Do tego stopnia, że wpychano tam pewne artykuły. Nawet Agatona Gillera „Ojczyzna” współpracowała z Bałaszewiczem-Potockim i zachwycała się tekstami, które on podsyłał. Trzeba więc bardzo uważać, zanim zacznie się traktować teksty z tych czasopism jako przejaw realnych poglądów emigracji. Niestety nie ma już materiałów Rapperswilskich, gdzie byłaby jakaś możliwość sprawdzenia, jak [dalece] tego rodzaju wypowiedzi emigracji popowstaniowej, reprezentującej głównie epigonów powstańczych, są wypowiedziami inspirowanymi przez agenturę i stronę rosyjską, której zależało na skłócaniu Polaków.

Jerzy Borejsza: Na jakiej podstawie to mówisz? Na podstawie wydanych przez Rafała Gerbera raportów rosyjskiego szpiega Bałaszewicza-Potockiego? Są w najwyższym stopniu bałamutne. Znaczna ich część to jawne zmyślenia. Gerber miał do nich sporządzić przypisy, ale był już chory, oddając je do wydawnictwa.

Andrzej Nowak: Wspaniały materiał do tego jest w bibliotece Polskiej Akademii Umiejętności.

Jerzy Zdrada: Są broszury, które były ekscerptami z „Demokraty”, a potem „Głosu Wolnego", finansowane i wydawane anonimowo w Londynie za pieniądze Bałaszewicza-Potockiego.

Maciej Janowski: Znaczenie kwestii narodowościowej w powstaniu styczniowym w moim przekonaniu polega na tym, że znajdujemy się jakby w przeddzień startu nowoczesnych ruchów narodowych. Kwestia narodowościowa w 1905 r. jest zupełnie inna, bo nawet w przypadku białoruskim napotykamy już w 1905 na sformułowane idee narodowe. W 1863 r. (w zaborze rosyjskim, nie mówię o Galicji) jest jeszcze godzina zero. Nie jest 
jasne, czy Kalinowski jest działaczem białoruskim, czy polskim powstańcem, który uważa, że trzeba jakoś chłopów poruszyć. Jest fascynującym i dla mnie wciąż niejasnym problemem, na ile w tych różnych antagonizmach między konspiratorami czy powstańcami z Królestwa a działaczami z Litwy są - obok zwykłych rywalizacji regionalnych - widoczne pewne antecedencje późniejszych odrębności o charakterze narodowym. Ustalenie tego wymagałoby bardzo uważnej lektury tekstów źródłowych z wychwytywaniem zmiennego znaczenia pojęć.

Jerzy Zdrada: Te procesy trwały. Po pięćdziesięciu latach od powstania mamy ruch krajowców. Wobec tego jest taka tendencja, by patrzyć na to, co się zdarzyło, jako na zapowiedź tego, co było potem. To bywa mylące. Ja byłbym ostrożny.

Andrzej Nowak: Po 1990 r. powstała bardzo ciekawa obszerna historiografia litewska, białoruska i ukraińska (ta ostatnia może trochę uboższa pod tym względem). To ogromna zdobycz, której myśmy jeszcze nie przetrawili. Dzięki niej możemy po nowemu spojrzeć na te problemy.

Jerzy Zdrada: Jest jeszcze jedna tendencja tej historiografii, aby wszystkich którzy pochodzą z tego obszaru, a dotychczas byli zaliczani wyłącznie do kultury polskiej, uważać za tutejszych i adaptować ich do własnych [koncepcji], trzymając na drugim planie ich polskość. Nie mam nic przeciw temu, bo oni sami bardzo często mówili, że są związani z tymi ziemiami. Na przykład tłumaczy się pamiętniki polskie na białoruski. Nie widzę w tym nic specjalnie złego pod jednym wszak warunkiem - że nie zaciera się faktu, że owi ludzie reprezentowali polską tradycję polityczną. Maciej Janowski: To wszystko jest jednak bardziej skomplikowane. Z jednej strony, o czym mówił prof. Zdrada, jest przesadą, czy może nawet mistyfikacją, zaliczanie wszystkich, czy wielu, działaczy polskich na ziemiach wschodnich do „lokalnych” - białoruskich, ukraińskich czy litewskich tradycji politycznych. Z drugiej strony jednak wydaje mi się, że istnieje niebezpieczeństwo przeciwne, a mianowicie jednoznaczne utożsamianie z polskością historycznych elit społecznych - przede wszystkim szlachty na dawnych ziemiach wschodnich Rzeczypospolitej w XIX w. Ten błąd popełnia zarówno część historiografii polskiej, absolutyzująca rolę Polaków na kresach, jak i część (bardziej tradycyjna) historiografii ukraińskiej, białoruskiej i litewskiej, zbyt jednostronnie podkreślająca demokratyczny, „postępowy” charakter własnych ruchów narodowych w opozycji do szlacheckiego ruchu polskiego. Wydaje mi się jednak niewątpliwe, że pewna (jak duża? nie wiem) część szlachty i inteligencji polskojęzycznej nie miała wykrystalizowanej polskiej świadomości narodowej. Istniały różne formy tożsamości lokalnej, terytorialnej, hybrydalnej (Platon Kostecki jest doskonałym przykładem) i dokładniejsze badania ujawniłyby prawdopo- 
dobnie, że wiele tych postaw miało istotne znaczenie dla rozwoju ruchów narodowych innych niż polski. Tak więc polska świadomość szlachty i inteligencji na ziemiach włączonych do cesarstwa nie wydaje mi się bezdyskusyjna.

Andrzej Nowak: To ogromny temat, na którego rozwinięcie nie ma już teraz czasu. Pozwolę sobie zwrócić uwagę, że jest coraz wnikliwiej badany przez takich choćby badaczy, jak Leonid Gorizontow z Moskwy, Darius Staliūnas z Wilna, Michaił Dołbiłow z Woroneża (już niestety zmuszony do emigracji do USA) czy Henryk Głębocki z Krakowa.

Powstanie szlacheckie, powstanie inteligenckie

Jerzy Zdrada: W związku z tym, że mamy problem Królestwa, Kresów, Galicji, czasem mi się nasuwa myśl, że zamiast mówić „powstanie styczniowe”, trzeba by mówić o powstaniach styczniowych, które nieco inaczej przebiegały na różnych terenach. $\mathrm{O}$ ile te elementy, o których panowie tutaj mówili, powstania jako ruchu szlacheckiego są wyraźniejsze na Białorusi, to o tyle w Królestwie już bym się o to spierał. Powiedziałbym, że tu było wręcz powstanie ludowo-miejskie. To wiemy chociażby z książki Franciszki Ramotowskiej Tajemne państwo polskie ${ }^{9}$. Rzecz opierała się organizacyjnie na środowiskach inteligenckich, na ludziach z kręgów takich, które obecnie byśmy nazwali inteligenckimi, ale wspierana była przez ziemiaństwo, które się podporządkowało dyrektywom rządu - płaciło podatki, dostarczało kontyngentów - tak jak się podporządkowuje władzy państwowej. Maciej Janowski: Ten element inteligencki w Warszawie w przededniu powstania jest bardzo ładnie pokazany przez Barbarę Petrozolin-Skowrońską w książce Przed tą noca ${ }^{10}$.

Jerzy Zdrada: To nie jest tylko cecha Warszawy, która była bez wątpienia głównym ośrodkiem. Jak się popatrzy na to, kto wspierał powstanie w Galicji, to w gruncie rzeczy znajdujemy tam również inteligentów. Inteligentem, mimo że pochodzenia szlacheckiego, był taki Kajetan Koźmian, który był agentem Rządu Narodowego między Paryżem a Warszawą, prowadził biuro paryskie. A Lucjan Siemieński, a Józef Szujski, którzy pracowali w gazetkach?

Andrzej Nowak: Ponad stu studentów mojego niezbyt wielkiego wówczas uniwersytetu.

\footnotetext{
${ }^{9}$ F. Ramotowska, Tajemne państwo polskie w powstaniu styczniowym 1863-1864. Struktura organizacyjna, t. 1-2, Warszawa 1999-2000.

${ }^{10}$ B. Petrozolin-Skowrońska, Przed ta noca, Warszawa 1988.
} 
Jerzy Zdrada: Tak. Wtedy uniwersytet w Krakowie miał czterystu studentów. Ów miejsko-inteligencki charakter konspiracji powstańczej jest dobrze widoczny, jak się spojrzy na organizację lwowską. Lwów był dwukrotnie większy od Krakowa. Organizacja tamtejsza opierała się na adwokatach, na studentach - tak jak wszędzie - i na mieszczaństwie, nie tyle kupieckim, ile rzemieślniczo-przemysłowym. Dopiero na dalszym planie są panowie Podolacy, którzy mają ogromne pretensje do przejęcia całej władzy, bo dają pieniądze. Cały pas nadbrzeżny, dzięki któremu szła pomoc do Królestwa, opierał się na ludziach pogranicza inteligencko-mieszczańskiego.

Maciej Janowski: To zupełnie co innego niż taki stereotyp powstania styczniowego jako ruchu romantyczno-szlacheckiego: $\mathrm{z}$ tego, co było powiedziane, widać wyraźnie, że nawet jeszcze przed uwłaszczeniem dokonuje się istotna zmiana społecznego charakteru polskiego ruchu niepodległościowego w porównaniu np. z powstaniem listopadowym.

Andrzej Nowak: Jeden stereotyp, jaki czasem ożywa w odniesieniu do powstania styczniowego, to Rozdziobia nas kruki, wrony Stefana Żeromskiego, drugi zaś znajdujemy u Artura Grottgera. Tutaj chłop zdziera buty z trupa powstańca lub donosi na oddział, a tam szlachcianka pięknego młodziana żegna. Są elementy prawdy w jednym i drugim, rola kobiet też jest niezwykle ważna i do docenienia w powstaniu styczniowym i jego przygotowaniu, i potem - w żałobie narodowej.

Jerzy Zdrada: Zdaniem Fiodora Berga bez kobiet nie byłoby powstania.

Andrzej Nowak: To jest ważna obserwacja wnikliwego obserwatora. Tak jak Pan profesor powiedział, to jest może ostatnie powstanie Pierwszej Rzeczypospolitej w tym sensie, że sięgało po granice I RP, a przynajmniej próbowało; ostatnie w tym sensie, że jednak szlachta była ważną grupą społeczną, ale na pewno już nie jedyną. I co ważniejsze, jak zawsze w robocie historyka, i tu się sprawdza - zróżnicowanie. Nic nie jest proste. Inaczej wygląda powstanie na północnym Mazowszu, na Podlasiu, inaczej na Sandomierszczyźnie, czyli tam, gdzie to Żeromski widział (tam akurat wygląda trochę jak w jego opowiadaniu - chłopi są raczej przeciw). Na podstawie wyrywkowej sondy Andrzej Chwalba w swej syntezie przedstawił taki obraz powstania jako wojny domowej - tzn. chłopi są u niego całkowicie przeciwko, widać ich w strażach wiejskich sformowanych przez Rosjan, a jeśli trafiają się po stronie powstańców, to tylko na zasadzie odrobku pańszczyzny - pan im kazał, to zamiast orać czy siać, czy ze sprzężajem służyć, idą do powstania. Tak bywało w Kieleckiem czy Sandomierskiem, a zupełnie inaczej było tam, gdzie żyła mocna drobna szlachta zaściankowa. I na Żmudzi - tam jest inna przyczyna - wspólne zagrożenie katolicyzmu przez bardzo represyjną politykę carską wobec religii, czego nie było na Podlasiu. Dam dwa wyrywkowe przykłady - 
np. w Siedlcach z akt naczelnika siedleckiego wynika, że wśród zatrzymanych jest 288 chłopów i 352 przedstawicieli obu grup szlacheckich. W guberni kijowskiej natomiast 67 proc. zatrzymanych stanowi szlachta, 9 proc. jednodworcy i 7 tylko proc. chłopi. To pokazuje różnice między regionami. Tu niemal w ogóle chłopów nie było, a tam była ich większość. To samo jeśli idzie o północne Mazowsze, to samo w odniesieniu do Siedlec czy Podlasia - duży udział chłopów: na płn. Mazowszu 368 osób ze szlachty, 468 chłopów, 75 urzędników. Inteligencja jest ważna dla tworzenia programów, inicjowania, ale nie dla przebiegu powstania w terenie. Tam chłopi i zaściankowa szlachta byli liczebnie najważniejsi. Nie można tylko skupiać uwagi na inteligencji. Jeśli dla niej powstanie miało znaczenie, to przede wszystkim w swoich skutkach. Ono stworzyło inteligencję, jej nowy typ i etos, na skalę masową przez to, że ludzie zostali wyparci z urzędów zależnych od państwa rosyjskiego i szukali miejsca w wolnych zawodach, musieli je znaleźć. Aktywizowali się więc na niwie społecznej. Wyparci zostali z roli urzędników zaborczego państwa, co było skutkiem powstania styczniowego.

Jerzy Borejsza: Jest mnóstwo stereotypów równoległych związanych z powstaniem. W książce, którą sobie bardzo cenię, tj. Historii Polski Jerzego Zdrady, na okładce jest Grottger. Macie tę matrycę. Kiedy dałem do „Gazety Wyborczej” artyku1 ${ }^{11}$ na 150. rocznicę powstania, zilustrowałem go oryginalnymi zdjęciami, a redakcja zastąpiła je Grottgerem, bo Grottger jest rozpoznawalny. Rzecz druga - otóż Józef Piłsudski, którego wiele poglądów podzielam (jego pogląd na Wielopolskiego też), otóż on stworzył pewien mit powstania, który stał się ideologią II Rzeczypospolitej. W tym micie mieściła się również ta tajemnicza pieczątka Rządu Narodowego i jej magiczne działanie itd. Między tym a rzeczywistym jej oddziaływaniem była chyba duża różnica. Jak mocno to było wbite w umysły całego pokolenia, to mogę potwierdzić, bo ja w czasie wojny na ulicy Smolnej niedaleko kamienia Traugutta, któryśmy wznosili na stulecie powstania, uczyłem się już tego kultu pieczątki jako malec na tajnych kompletach. Trzeba uważać z różnymi mitologiami.

Jerzy Zdrada: Mit pieczątki, tajemnego państwa i Rządu Narodowego to nie jest późniejsza sprawa - w marcu 1863 r. niejaki Mieczysław Romanowski napisał we Lwowie wiersz o Rządzie Narodowym. Co on o nim wiedział? On szykował się do tego, żeby pójść do powstania. Wziął udział w dwóch wyprawach, zanim zginął. Sama myśl, że jest tam gdzieś Rząd Narodowy, działała na tych ludzi.

Maciej Janowski: Nazwa została świadomie przejęta z 1831 r.

${ }^{11} \mathrm{~J}$. W. Borejsza, 150 rocznica insurekcji 1863 roku, „Gazeta Wyborcza”, 19-20 I 2013. 
Jerzy Zdrada: Naturalnie i pierwsza pieczęć Komitetu Centralnego, i tymczasowego Rządu Narodowego była wzorowana na pieczęci państwowej $\mathrm{z}$ powstania listopadowego. Ma tarczę dwudzielną. Dopiero w maju $1863 \mathrm{r}$. wprowadzono tarczę trójdzielną, choć ona się już przedtem pojawiała jako symbol. Czasem myślimy, że ta mitologia wytworzyła się grubo po fakcie. Tymczasem to działo się na bieżąco.

Andrzej Nowak: Do aspektu społecznego chciałbym dorzucić jedną rzecz, bo wydaje mi się ważna, czyli ogromną rolę księży. Czy jednak księży zaliczyć do inteligencji? Więzi między wychowankami jednego seminarium były tak silne, że ułatwiały kontakty konspiracyjne, zjazdy wojewódzkie księży przed powstaniem, bez których nie byłoby insurekcji - bez tych kilkuset duchownych, którzy swoim autorytetem pociągnęli i szlachtę drobniejszą, i chłopów oczywiście. To było bardzo ważne i to otwierało pytanie o pomost między kwestią społeczną, narodową i religijną - o katolickość tego powstania. To jest wielki temat, który podejmuje na nowo ośrodek studiów skupiony wokół prof. Eugeniusza Niebelskiego.

Maciej Janowski: Niestety, musimy powoli kończyć, chociaż chciałbym jeszcze porozmawiać o kilku ważnych problemach - o indywidualnych dylematach, o postawach jednostek i ogólnie - o psychologicznym aspekcie powstań czy rewolucji.

Jerzy Borejsza: Może na dwóchsetlecie powstania styczniowego będziemy się znowu spierać o sens i szanse powstania?

Jest rzeczą znamienną, że kwestię szans powstania styczniowego Stefan Kieniewicz postawił odrębnie w szerszym ujęciu tylko w wykładzie po francusku, ogłoszonym później w postaci broszury równolegle do jego monumentalnej monografii ${ }^{12}$. Pyta Kieniewicz, czy należy krzewić w Polsce kult bohaterów, który niczego nie przynosi (héroïsme inutile). Jego zdaniem „nie można twierdzić, że szanse powstania były całkiem zerowe”, ,nigdy jednak nie były zbyt zachęcające”. Jak wielu innych badaczy zwracał uwagę, że powstanie wybuchło w czasie niesprzyjającym. Uważał, że największe szanse miałoby około roku 1860. Pisał, że we wrześniu-październiku 1860 r. koniunktura międzynarodowa byłaby dla insurekcji sprzyjająca. Siły rosyjskie w Królestwie Polskim nie przekraczały 45 tys., z czego 14 tys. w Warszawie. Nie było jeszcze połączenia kolejowego. Rosji groziły rozruchy. Później w czerwcu 1862 r. otwarta została linia kolejowa Petersburg-Warszawa, którą przerzucano siły wojskowe. W styczniu 1863 r. stacjonowało już w Królestwie 100 tys. żołnierzy. Potem kilkakroć więcej.

\footnotetext{
12 J. Kieniewicz, Les chances de l'insurrection polonaise de 1863, Warszawa 1973.
} 
Problem szans powstania rozpatrywany z perspektywy lat sześćdziesiątych XIX w. jawi się inaczej niż dzisiaj. Stary namiestnik Michaił Gorczakow 27 lutego 1861 r. pisał do Aleksandra II, po salwach oddanych do demonstrantów pod Zamkiem: „Duch przewrotu rozwijający się w Europie, gdy każdy ma przed oczami wypadki w Italii, nie pozwala umiarkowanym [domyślnie - Polakom] sprzeciwiać się tym, którzy za wszelką cenę przygotowują rewolucję - najsurowiej zakazałem wojsku strzelać, ale i karabiny na mój rozkaz nie były nabite. Zabłocki kazał nabić i dać ognia, jak sądzę niepotrzebnie. [--] W naszym stuleciu dwukrotnie wojska francuskie nie mogły opanować powstania ludowego". A więc w roku $1861 \mathrm{w}$ oczach najwyższych władz rosyjskich powstanie ma jeszcze jakieś szanse. Rok później już szanse te traci. Ale współcześni często nie są tego świadomi. 